\title{
Corporate Social Responsibility and Firm Performance: The Moderating Role of Reputation and Institutional Investors
}

\author{
Marwan Alshammari ${ }^{1}$ \\ ${ }^{1}$ University of Texas, Arlington, USA \\ Correspondence: Marwan Alshammari, University of Texas, Arlington, USA. E-mail: \\ marwan.al-shammari@mavs.uta.edu
}

Received: March 9, 2015

Accepted: April 2, 2015

Online Published: May 25, 2015

doi:10.5539/ijbm.v10n6p15

URL: http://dx.doi.org/10.5539/ijbm.v10n6p15

\begin{abstract}
Drawing on the institutional theory, stakeholder perspective, and ownership literature on corporate social responsibility, this article sheds light on the relationship between the firm social performance and the financial performance of the firm. Singularly, the paper explores a moderating effect of both corporate reputation as a proxy for firm social activities' publicity and the institutional investors in the firm. The paper proposes that expected positive impact of both reputation and institutional investors on the relationship between CSR and firm performance. Such that, the firm can best benefit from CSR activities when it has a good reputation among major stakeholders. The effect of institutional owners is expected to positively moderate the relationship between CSR activities and firm performance. Overall, the paper suggests that corporate ownership structure, as well as corporate consistent reputation will have influence on the extent to which a firm may benefit from its CSR activities which would open a new avenue for research on governance structure with regard to CSR and firm performance. Implications for both academics and practitioners are discussed and suggestions for future research are provided.
\end{abstract}

Keywords: corporate social responsibility, firm performance, institutional investors

\section{Introduction}

Corporate social responsibility has received growing interest from business scholars over the past couple of decades. The linkage between CSR and firm performance, however, has been a controversial issue among scholars as there has not been a consensus regarding the impact that CSR would have on firm performance. Building on the call made by Balogun et al. (2014) for a more integrative approach among theoretical arguments that are business related such as sense-making, power, and socio-materiality, the current study aims at examining the moderating effects of institutional investors and corporate reputation on the relationship between corporate social responsibility and firm financial performance. One view in existing literature points out that firms that act responsibly in their social context can gain a competitive advantage and therefore improve their financial performance. (McWilliams \& Siegel, 2001), for example, noted that there is an optimal level of CSR that managers can control based on an economic view of cost vs benefits, and that CSR does not have a significant level of impact on firm financial performance. (Andersen \& Olsen, 2011) used the operating income of the firm and found robust correlation between a firm's CSR level and its financial performance. (Branco \& Rodrigues, 2006), argue that firms benefit from initiating a social engagement and activities and those accrued benefits can be internal by improving a cooperative culture that would enhance and enrich its Know-Hows, and externally by contributing to its overall reputation.

Drawing on institutional theory, (Jennings \& Zandbergen, 1995) asserted on the need for such ethical and socially desirable actions, therefore, argued that firms can develop a sustainable and true presence, as well as a sustainable bionetwork for the firm. (Donker, Poff, \& Zahir, 2008) found a significant and positive relationship between CSR index and firm performance. Furthermore, they reported that firm values and ethics were found to be strongly and positively correlated with firm book value, suggesting that such CSR activities could be strategically critical asset in boosting the value of the firm. (Dutton \& Dukerich, 1991) also argued that firms can achieve a collective and stronger involvement of its employees, which in turn increase their commitment and productivity, thus be reflected positively on its performance.

In this paper, I revisit the relationship between CSR and firm performance, taking into consideration a possible 
moderating effect of corporate reputation and institutional investors. Building on the existing literature, I propose a more integrative model. It is argued that stakeholders and major constituents play crucial role in the firm's level of performance. There is a need for a more integrative approach through which our understanding of the impact of CSR on firm performance can be improved. Consistency and social engagement are major factors in order for firms to benefit from such CSR activities (Freeman, 1984). Therefore, my study proposes that whereas CSR is imperative to the firm and will have a positive impact, it should be noted that when a firm's reputation is not at considerable level from the stakeholders' perceptions (Herremans, Akathaporn, \& McInnes, 1993), the CSR rating even if high, will not add a decent value, nor the contribution to the firm financial performance will be manifested. However, when a firm has already a strong and well-established reputation, only then a firm can expect a strategically competitive advantage as it increases its CSR engagement and activities (Branco \& Rodrigues, 2006). CR has become a vital business issue, with a reputation that can either activate the remuneration from the concerned stakeholders, or offset the positive impact that an emerging CSR activities may produce, it is noteworthy then that firms that have already created and maintained their reputation are expected to realize soon the added value by their social engagement which will be reflected in the firm's profitability (Herremans et al., 1993).

The study builds on corporate ownership structure literature, particularly, institutional ownership in the firm and the role it plays in aligning the CSR initiatives with stakeholders' expectations, firm's best interest, and also minimizing the likelihood of self-interest social activities that a CEO might undertake. (Hartzell \& Starks, 2003) found that institutional investors play significant role in mitigating agency problems and closely monitoring CEO behavior. (Ferreira \& Matos, 2008) also found that firms with higher levels of ownership by independent institutions exhibit lower capital expenditures and better monitoring role, which was reflected on a better firm performance. (H. L. Petersen \& Vredenburg, 2009) suggest that these institutions do prefer socially aligned organizations, and their decisions after investing whether to hold or sell their shares depend on several factors, their results from surveying many representatives of institutional investors show that CSR is highly considered and perceived as a mechanism through which risk is mitigated through better relations with several stakeholders, and enhancing the firm access to resources. Therefore, it is noteworthy to test the relationship between the presence of institutional investors and the extent to which CSR will have an effect on a firm performance, I expect that these institutional owners will play a positive moderating effect to enable CSR positive impact and create mechanisms through which they enjoy economic benefits.

\subsection{Corporate Social Responsibility and Firm Performance}

Stakeholders' perspective suggests that firms would be better off when they know their stakeholders demands, and try to meet them. (Freeman, 1984) argued that firms that satisfy their stakeholders are able to create strategically competitive advantage. (Gove \& Janney, 2011) suggested that firms can benefit from CSR enhanced reputation when they undergo major crisis or scandals. According to them, safeguarding part is best obtainable when CSR is high, and thus, financial performance will not be deeply harmed. This implication can be extended as well to the time of crisis in the whole market, where stakeholders will perceive firms with better CSP less negatively.

Campbell (2007) argued that firms engage in socially responsible activities because they respond to several actors in the environment. He grounded his argument on institutional theory prescriptions. Furthermore, he indicated that when firms are engaged in dialogues with their environs, they are best advised to respond positively to their stakeholders, the non-governmental organizations, and to the norms emerging in their environments.

Also, building on institutional theory, CSR performance will be greatly taken into consideration when institutions are weighing their available alternatives. For example, it is argued that institutional investors would prefer firms with better CSR ranking over those with low rankings. Consistent with this argument (Graves \& Waddock, 1994) reported that the number of institutions holding shares on a company is greater when the firm has better CSR performance indicators. The intangible resources have long been argued to be crucial in creating and maintaining a competitive advantage. Hall (1992) argued that it is crucial for firms to consider its intangible assets such as know-how and employee cooperation and collaborative work, and that it should be given more importance in drawing a firm's strategy. This implies great importance for the employees' loyalty and commitment, which can be enhanced through a CSR active engagement. CSR ranking takes into consideration employees' relations as a major indicator for a firm's CSR ranking. That being said, it is reasonable to assume that firms with better social performance will enjoy more collaborative work environment and employees commitment which would in turn improve its performance. This implication for the strategic importance of intangible assets is also supported by Turban and Greening (1997), who argue that CSR does add a strategic 
advantage to the firm by attracting and retaining talented employees. This reasoning supports the notion that in highly competitive industry, employees' satisfaction can be obtained by incorporating their perceptions into the work, which in turn increases their constancy and commitment to their firm, thereby, adding a value and sustaining talented employees.

It is also argued that firm's financial capabilities are major beneficiaries from CSR ratings. El Ghoul, Guedhami, Kwok, and Mishra (2011) for instance, found that firm's cost of equity will be cheaper for firms with higher CSR ratings. Lin and $\mathrm{Wu}$ (2014) found similar results. Dhaliwal, Li, Tsang, and Yang, (2014) provided more support to this notion revealing that the relationship holds even stronger for countries that are stakeholder-oriented. Additional support was reported in Reverte (2012), when it was found that that the relationship is even stronger in sensitive industries.

On the other hand, some scholars have raised some concerns regarding the financial impact of CSR. Among others Cox et al. (2004) studied the relationship between CSR and firm performance and found no relationship. McWilliams and Siegel (2001) suggested a neutral relationship between CSR and financial performance based on a firm-based view. They indicated that there is an ideal level of CSR managers can determine using a cost-benefits analysis. They employed a set of factors as independent variables including size, diversification, R\&D, government sales, consumer income, labor market conditions, and stage in industry life cycle. Aupperle et al. (1985) also reported no significant relationship between CSR and firm's profitability.

Contrary to these propositions, Hillman and Keim, (2001) found that when firm's social engagement is properly presented and fit their stakeholders' expectations, such action lead to value creation and positive impact on firm's financial performance. Russo and Fouts (1997) also provided support for the positive impact of CSR on firm's profitability. They studied 243 firms over two years, and used environmental ratings to address the relationship between CSR and firm's profitability. They found that adopting socially and environmentally responsible policies, indeed, lead to better financial performance. Moreover, they argue that when industry grows faster, this relationship holds stronger. Ekatah, Samy, Bampton, and Halabi (2011) found that regardless of the causal connection, CSR is found to be positively related to profitability of the firm. Almsafir (2014) also found CSR leads to improved firm's profitability and that financial performance is better off when firms are highly rated in their CSR indexes in comparison to other firms. Cochran and Wood (1984) found that the Average age of corporate assets is found to be highly correlated with social responsibility ranking.

Some researchers have argued that worse social performers have made more charitable contributions than other better social performers. Chen et al. (2008) studied three domains of social performance. They stated that those who have the worst social performance in the three domains (employee relations, environmental issues, and product safety), have made more charitable contributions to make up for their failure in these domains. The conclusion one can draw from this finding is that when firms do better job and comply to their code of ethics, as well as the industry code of ethics, they do not need to give as much money out as they would have to if they did not do well in their social performance. Furthermore, these results as suggested by Chen and colleagues (2008) found significant and hold true especially for the environmental and product safety dimensions of social performance, suggesting that in industries where product and environment matters, more attention should be paid to firm's social performance so firms can sustain their social power and avoid getting to the point where they will have to make up for their social failure by giving more money in charitable contributions.

The stakeholders' theory asserts on the need for continuity in meeting stakeholders' expectations, with accordance to their importance, as well as appropriate and most fit activities and initiatives. (Hond, Rehbein, Bakker, and Lankveld (2014) insisted that firms must pay close attention to their stakeholders and be consistent in sustaining their social performance, as well as political performance. This, in turn, creates a favorable situation under which firms may benefit through regulations, governmental support, and also improved reputation.

It has also been argued that firms with low innovation and differentiation strategies can utilize their CSP to improve their financial performance. (Hull \& Rothenberg, 2008), for example, argued that CSR performance has a strong impact on firm financial performance when the firm is at low-innovation and differentiation level. This mechanism can also be used as a leverage in the firm's long term strategy to build upon this advantage to improve its strategic domain in the future, such as taking further steps towards expansion either geographically or in its product lines gradually until it has gained a sound platform of strategic advantages.

More importantly is the consistency in CS performance. Hull and Tang (2012) argued that a consistent social performance is a condition that under which firms can only start realizing synergies and improve their financial performance. This notion is consistent with other studies. Wang and Choi (2013) for example, insisted that in order for firms to enjoy the CSR returns, they must be consistent. They concluded that firms that are 
knowledge-intensive must more than others pay more attention to their CSR performance, as such action would have a stronger positive impact on their overall financial performance through maintaining their know-hows secrecy and thus keeping one of their core competencies.

The dynamic nature of today's most business environments requires firms to react in a timely manner to any move in the market. CSR is a strategic step firms can incorporate into their strategy and can therefore utilize it in a profitable manner. The most recent CSR index has incorporated six dimensions, of which employees relations, workplace, and society-oriented are major dimensions. Hatch (1993) developed a model that he called cultural dynamics, it insists on the importance of the courses of actions through which a firm's social image is manifested and symbolized. Based on this, one can argue that CSR as in its fundamental definition is one of the crucial duties that could articulate the firm's dynamic aspects in its economic and social context.

This notion found empirical support in the literature. El Ghoul et al. (2011) found that CSR affects the cost of capital, indicating a positive relationship between firms with better CSR score, exhibited cheaper equity financing. Firms that try to satisfy their stakeholders will definitely benefit on two dimensions, one is that they are building a good identity and image, and the other is cost minimization by using environment-friendly policies in their production and services. For example, firms can make a good argument of their socially and environmentally good behavior of paperless work, while they are actually minimizing their costs. Also consistent with (McGuire, Sundgren, \& Schneeweis, 1988) who argued that risk is reduced with high commitment to CSR. Support for this notion is also found in Attig, El Ghoul, Guedhami, and Suh (2013) who found that credit agencies give higher rating to firms with socially responsible acts. In line with notion, finance literature reported strong support. Jiraporn, Jiraporn, Boeprasert, and Chang (2014) found that firms with good CSR rating enjoy advantageous credit rating. In sum, firms can surely be in advantageous situation by being socially responsible. It is in the firm interest to have a good credit rating and reduce its cost of capital. Firms can then be better off in terms of being able to access the cash they might need in their strategic plans, and therefore, have better chances relative to other competitors with low CSR performance.

Waddock and Graves (1997) found that firm's level of CSR have a positive impact on its financial performance This effect, according to them, can be best noticed in the subsequent years, supporting the notion that consistency is important in generating the financial returns of CSR. Barnett (2007) proposed that a firm's current stock of SIC is positively related to its prior CSR activity. That is, a firm can benefit from CSR in building a good influence on its stakeholders, he then proposed that the effect of an act of CSR on stakeholder relations and SIC (stakeholder influence capacity) are amplified in the presence of evidence of its effect on social welfare In other words, a firm needs to show some evidence that its activities have contributed positively to its stakeholder welfare. This reasoning underlies my proposition that a firm that does not air its CSR effectively and in a timely manner would not be able to capitalize on the CSR activities. Therefore, it is important that the social engagement and reach of a firm -which mainly depends on its ability to continuously make its CSR activities-go noticed and then it can expect an improvement of the effect of such activities.

Also form stakeholder perspective, firms can gain stronger support when they are perceived as socially responsible from the stakeholders' perceptions. Maignan and Ferrell (2004) proposed that firms can, indeed, generate more support from stakeholders when they are seen as socially responsible. Further support for this notion is reported in (Mukherjee \& He, 2008). They argued that firms can create competitive advantage by being socially responsible. Their model suggests that the three major stakeholders (Managers, employees, and customers) evaluate the company based upon its identity, and thus CSR is the major pillar of this evaluation. In so doing, firms can influence such evaluation and benefit from their behavioral consequences and thus obtain superior performance. Sen, Bhattacharya, and Korschun, (2006) found that CSR will be rewarded from stakeholders. Not only in the consumption domain, but more importantly in the employment dimension, as well as the investment dimension. Stakeholders respond positively and strongly once the firm's social activities become genuine and consistent with their perceptions. Vlachos, Tsamakos, Vrechopoulos, and Avramidis (2009) insisted on the importance of consumer trust, in order for the firm to benefit from CSR and create competitive advantage and sustain it, this supports the notion that firms that are consistent in their social performance can enjoy a strong support from their stakeholders, and thus improve their financial performance... Building on this, my first proposition in this research is:

Proposition 1: The level corporate social performance of the firm will be positively related to its financial performance.

\subsection{Corporate Reputation as a Moderator}

Weigelt and Camerer (1988), among others, defines the reputation of a firm as "set of attributes inferred from the 
firm's past actions and ascribed to the firm". Miller and Plot (1986) argue that one of the reputation building behaviors firms can adopt is selling high-quality products, and charging higher prices. One might ask then, could this reputation be perceived as a socially responsible behavior? From a stakeholder perspective, it might be seen as a single dimension as it commits to producing differentiated and high quality products. However, this does not qualify the firm to realize rents if it has a low CSR ratings. This is a strategic action that reflects a differentiation strategy, behavioral reputation building (Miller, R. and C. Plott. 'Rents for reputations'. Paper presented at Western Finance Association Meetings, 1986). In that sense, (Shapiro, 1983) argued that firm's reputation is mostly built upon their products 'and services' qualities, and that when they produce a unique and differentiated products they can enjoy premium returns for their high-quality product. That is, a reputation is built over time, needs to exist along the line with the firm's CSR independent rating, in order for firms to achieve better performance. It is the sense of math, when we have a positive number that is added to a negative number, there are three possible outcomes: $+\mathrm{A}+\mathrm{B}$, if $\mathrm{A}>\mathrm{B}$ we know for sure the outcome is positive, if $\mathrm{A}<\mathrm{B}$ we know for sure the outcome is negative. If $\mathrm{A}=\mathrm{B}$ the outcome is 0 . In the context of CSR and reputation, the same logic applies, and both CSR and existing reputation should be positive to trigger the feasibility of CSR.

Firm's reputation has been argued to affect firm's financial performance. For instance, Turban and Greening (1997) built on the social identity theory and found that CSR performance is positively related to the firm's reputation and attractiveness as employers, and thus they can attract potential talented employees. This, however, can establish an advantage in industries where competition for the human capital is high and where such resources make a difference. Rationally speaking, employees would want to work for a firm that has a well-established reputation and has a unique brand name that they can have loyalty and commitment toward. In the human resource perspective which stems from the RBV, firms that have strategic know-hows such as human capital skills and technological distinctive assets will utilize these key competencies to craft and sustain a competitive advantage, the relationship between these two constructs is positively related as suggested by Arendt and Sebastian (2010) and that corporate reputation plays moderating role in such relationship. In particular, the activities that firm undertakes to improve its reputation, in which CSR is the major pillar, are important to create a better reputation and therefore enhance the human capital commitment.

The importance of social performance lies in its ability to either enhance or harm a firm's reputation. Social performance importance also vary across industries, industries where stakeholders perceptions focus more on environmental dimensions of CSR will push firms to do a better job on such direction as to meet the expectations of their stakeholders, and by doing so, reputation can be improved and sustained resulting in better relations with stakeholders which will be rewarded in subsequent years. In this sense, S. J. Brammer and Pavelin (2006) found that CSP vary across sectors, and that a fit must be established between stakeholder's expectations and a firm social-oriented activities in order for the reputational effect to be positive.

Corporate reputation has been defined as a "set of collectively held beliefs about firm's ability to satisfy the interests of stakeholders" (Beheshtifar \& Korouki, 2013), they argued that it also means "collective judgments of a corporation based on assessment of its financial, social, and environmental impacts attributed to the firm", this, indeed, means that a firm that is positively perceived by the stakeholders and independent observers would most likely have a better image than other firms that are less responsive to stakeholders demands. Beheshtifar and Korouki, (2013) also argued that reputation can be as success contributing factor as failure as well if not well-established and sustained.

Also, researchers have found that continued good reputation of the firm will eventually pay off, reputation as mentioned previously can be seen as either perceptions of stakeholders or judgment based upon activities, since those activities are in fact tightly linked to firm social performance, it indeed suggested that such activities will create both cognitive and judgment that are positive. Eberl and Schwaiger (2005) studied 30 German firms and after adjusting for past performance effect, they found that the reputational effect is positively related to future firm performance, although, they suggested that there is slight probability for generalizability, but these findings are consistent with other findings that suggest the same relationship holds true even for U.S firms.

The strategic actions of firms affect its performance, and it is built upon the available resources for the firm that it can utilize to maximize the shareholders' value. Strategy scholars have suggested that corporate reputation is an important intangible asset that the firm can use to create or sustain its competitive advantage. Hall (1992) argued that in the context of strategy, reputation and know-how are indeed intangible resources for a firm, based on a national survey study of the chief executives in the U.K, he concluded that reputation and know-how are the most contributing intangible resources for business success and thus suggested that such resources must be taken into consideration as major factors for the strategic management process. Turban and Greening (1997) builds upon the social identity and signaling theory and proposes that CSR is positively related to firm's reputation and 
attractiveness of talented employees, thus can create a competitive advantage.

By undertaking a socially responsible actions, a firm can develop a collective and collaborative environment that would be more efficient and effective, I mean by efficient and effective is that a firm collective actions which are the actions taken by its managers, shareholders, and employees who are important group of internal stakeholders (Stuart, 2002), are consistent, socially responsible, and committed to a collectively acceptable beliefs and norms it would be much easier for the firm to automatically activate its employees to be more productive, to be committed, and loyal to work as the internal environment has been established by all the internal stakeholders and these beliefs are agreed upon. In this sense, Dutton and Dukerich (1991) found that the organization's image and identity create motivations for its employees and this and turn creates patters for the future actions of the firm. Freeman (1984) defined stakeholders as "those groups who can affect or are affected by the achievement of an organization's purposes", an integrative strategy in satisfying both groups of stakeholders internal and external would help the organization receive full support from the employees which lead to better firm performance and productivity as suggested by Ashforth and Mael (1989) who argued that organizations that succeed in aligning a consistent identification for their employees would get full support from this group of stakeholders.

In a literature review done by Chun (2005), he concluded that corporate reputation is "umbrella construct, referring to the cumulative impressions of internal and external stakeholders", furthermore, the author also insisted on the importance of such construct in creating a positive perceptions at the stakeholders' side such as suppliers, customers, employees, and other relative stakeholders. This supports the view that reputation works as a either enhancer or ballast of the relationship between firm's social performance and firm financial performance.

Firms need to make their social activities relevant to their domain, important to their major stakeholders, seen and noticeable, and more importantly strategized and sustained in the most profitable way to the firm so it can capitalize on such reputation.

(Dickinson-Delaporte, Beverland, \& Lindgreen, 2010; Herremans et al., 1993; Mallin \& Michelon, 2011; Wrolstad \& Krueger, 2010) among many other scholars have studied the direct relationship between corporate reputation and either CSR or firm performance. However, as I propose in my study, there is a quiet slight, yet, unseen and under-researched difference between the two in their correlation and individual effect on firm performance. A question that worthwhile to understand this conflicting issue is as follows: suppose a firm decides to engage in many social activities and make charitable contributions, the firm has a bad history and negative image at the stakeholders' side, will its social activities represented by its independent rating or by its own disclosure work immediately? The questions draws a picture of what could improve our understanding on how existed strong reputation will enable a stronger positive impact of the CSR or a bad reputation will cancel out such effect. In fact, a study done by Chen et al. (2008) found that worse social performers have made more charitable contributions than other better social performers, this provides a strong support on the need for established reputation that will positively moderate the relationship between CSR activities and firm performance. It can be argued that reputation works as the enabler or the canceller in the sense that it works in upward direction (enhancer) when it has been already existed and established in the social context (stakeholders perceptions), or as stabilizer when the reputation is moderate and CSR is high, and as leverage when the CSR is high and reputation is low, yet, if CSR is maintained in the long term, reputation will move upward as well and keep moderating the relationship between the CSP and firm performance. For example, a firm that competes for talented employees with high CSR performance, but with a negative reputation will not be able to attract the most unique applicants (Chen et al., 2008). Turban and Greening (1997) among others suggest that good reputation will attract the talented employees, and that firms can build a competitive advantage through a well-established reputation, along with a good and decent CSR rating (Mukherjee \& He, 2008).

Dickinson-Delaporte et al. (2010), Sur and Sirsly (2013) among others studied the relationship between corporate reputation and firm performance using stakeholders approach, the results have indicated that the concerned stakeholders build reputation of firms based upon different approach, they found that stakeholders use market and accounting-based measure to evaluate firm's performance, then they use institutional signals to judge firms' compliance and responsiveness to the social norms, the firm's strategic explicit vision as a measure of its strategic stances. Then, it should come as no surprise, that firms with good reputation will enjoy a favorable evaluation to large degree regardless to the level of their social engagement as long as those firms do not violate the social norms and engage in scandals, however, these firms that have a good reputation can then strategically create competitive advantage by a stouter social performance, which in turn will be rewarded by the stakeholders. 
Riordan, Gatewood, and Bill (1997) defined corporate reputation as a "function of organizational signals which determine the perceptions of various stakeholders regarding the actions of an organization", reputation has been linked to the sustainable satisfaction of internal and external stakeholders (Dickinson-Delaporte et al., 2010; Herremans et al., 1993; Wrolstad \& Krueger, 2010). It is in the firm's best interest to take advantage of its reputation and act accordingly in the social context, in so doing, it uses what has been called a socio-materiality approach (Balogun et al., 2014) to capitalize on its pre-established reputation in the market context and the social context, thus improve its financial performance by the expected reward from stakeholders.

In fact, there is a decent body of research that suggests consistency and uniformity are crucial factors to enable CSR positive impact. Oikonomou, Brooks, and Pavelin (2014) builds on the social judgment theory and studied the relationship between CSR uniformity and firm performance, the findings support the notion of uniformity and continuity, indicating that firms with pre-established and uniform indicators of CSR strategically outperformed firms with mixed picture that has opposite directions of its CSR and reputation.

According to Fombrun and van Riel (1997), each of the following discipline has used its own definition of reputation:

Accountancy: Reputation seen as an intangible asset and one that can or should be given financial worth.

Economics: Reputation viewed as traits or signals. Perception held of the organization by an organization's external stakeholders.

Marketing: Viewed from the customer or end-user's perspective and concentrating on the manner in which reputations are formed.

Organizational: Viewed as the sense-making experiences of employees or the perception of the Behavior organization held by an organization's internal stakeholders.

Sociology: Viewed as an aggregate assessment of a firm's performance relative to expectation and norms in an institutional context.

Strategy: Reputation viewed as assets and mobility barriers. Since reputations are based on perception, they are difficult to manage.

I argue that firms that engage in CSR activities, without being able to communicate well with their stakeholders, and thus make their activities noticeable will fail to enjoy rents from their social engagement, reputation is always needed as a way to make the firm's social strategy works better.

For instance, in industries where the competition is fierce, the firm will need to make sure that its CSR activities go public and make sure to communicate well its message to its consumers. The benefit of CSR activities are contingent upon an effective marketing of those activities. (Kemper, Schilke, Reimann, Wang, \& Brettel, 2013) found that marketing had a significant and positive impact when the financial performance when the CSR is high, while it had low impact when the CSR is low.

In fact, scholars have argued that firms engage in CSR as a response to stakeholders pressure (Hooghiemstra, 2000), if so, then CSR activities can't pay off as a single strategy unless it is accompanied with good reputation, strong publicity, and effective marketing.

Proposition 2: The firm reputation will positively moderate the relationship between the firm's level of CSR and the firm financial performance. Such that firm performance will be best off when it has high level of CSR and well-established reputation.

\subsection{Institutional Investors, CSR, and Firm Performance}

Large institutional investors have become major player in the U.S corporations with ownership of half of U.S firms' equity. They have voting power that increases over time by increased activism in their involvement in firms' strategies, especially large institutional investors as argued by Davis and Thompson (1994). Thomsen and Pedersen (2000) found that such investors have important effects on the firm decisions making processes, and thus firm's performance and profitability and proposes that institutional investors would improve firm's profitability. Activism of shareholders, therefore can be a major player as well in shaping a firm's CSR strategy, in which those investors will have great incentives to ensure its feasibility and profitability.

Strategy scholars have long considered the relationship between board composition and firm strategic decisions, as well as the board composition and leadership structure on firm performance. David, Kochhar, and Levitas, (1998) for instance, found that institutional investors influences the compensation bundle of the CEO and link it more tightly to the firm long term performance. Scott (2014) found that institutional investors' presence pushes 
for more $R \& D$ investment which intends to engender long-term profits and enhanced performance. Bushee (1998) consistent with the Scott (2014). Bushee (1988) argue that institutional investors influence the firm's level of innovation positively by enhancing the R\&D process. The institutional investors have the capabilities to stress strategic issues and influence the directions of management towards more rigorous and profitable strategies through their shares.

Wright, Ferris, Sarin, and Awasthi (1996) argue that institutional investors have a positive impact on the risk-taking orientation of the firm as they are more concerned with the firm's long term financial performance. It is argued also that firms with institutional investors outperform their counterparts with less concentration of institutional investors, this in fact is a global phenomenon (Ferreira \& Matos, 2008).

Institutional investors are argued to favor investing in firms with better CSR ratings, CSR represents a major criterion used by institutions in making their investment decisions. Graves and Waddock (1994), found that as the firm's CSR level upturns, the number of institutions that become investors and hold shares in the firm increases. Also, Johnson and Greening (1999) found the presence of institutional investors improves firm's social performance, in particular, the employee relations, women and minorities, community and product quality, it should be noted that institutional investors' effect on firm financial performance have been found positive.

Peng and Yang (2014) studied the moderating effect of ownership concentration and found it has a negative impact on the relationship between CSR and firm performance, however, the study was done on Taiwanees companies and therefore, generalizability maybe limited due the country factors differences as well as other legal and social differences. Neubaum and Zahra (2006) argue that institutional ownership is positively associated with firm CSR level. McGuire, Dow, and Argheyd (2003) found that when the CEO long-term incentives and salary weakens the CSR performance, Cox, Brammer, and Millington (2004) also studied the relationship between institutional investors and firm CSR, they found long-term institutional investment is positively related to CSP, suggesting that institutional investors have more incentives to invest in socially responsible firms Johnson and Greening (1999).

Pfeffer and Salancik (1978) provided a new perspective on how firms must be effectively engaged in their external environments, as they do not have all the tactical means to sustain their core companies and maintain lucrative existence in the market. This view can be protracted to the context of institutional ownership in the firms. The attendance of institutional ownership can bound CEO opportunistic behavior, can build external linkages with outside resources, and can offer better information obtaining and processing on how and when a firm's actions can construct a competitive advantages for the firm. This will lead to the datum that when extant effectively, institutions can be great source in offering advice on the best way to exploit social performance, in fact this should be assumed as in their core duties, after they have made their decisions to invest in the firm.

Institutional investors, as archetypal of outside environment, are indeed, better able to align the firm's CSR doings with stakeholders' expectations, as well as what works to the best of the firm's interests. It is eminent that institutions are firmer in monitoring firm's performance.

Board characteristics have been argued to impact firm's strategic decisions, as well as its reputation, Musteen and Datta (2010) studied the relationship between board's size and structure in terms of outsiders and independence leadership style (separation between CEO and board chairperson), they found that both the size of the board and the percentage of outside directors are positively associated with reputation. Indeed, this is reinforced by the same logic of signaling and resource dependence theory as those outsiders have networking effects, and can also be viewed as a positive sign of how firms perform at both, social and business levels.

(Ahmed, Islam, Mahtab, \& Hasan, 2014; Cox, Brammer, \& Millington, 2004; Maitland, 2003; Waddock \& Graves, 1995) among others have argued that institutions have preferences when they make their investment decisions, moreover, it is argued that those institutions would favor firms with high CSR rating. As they make their decisions, institutions then will have sturdier incentives to guarantee their investment profitability and pay offs, they will have every reason to ensure that CSR activities be fit, appropriate, and sense-making through a profit-generating mechanisms.

Institutional investors have external networking capacities that a firm would not have otherwise (Pfeffer \& Salancik, 1978), they can better align the social activities with the best interests of the firm, they can also undo any social activities a CEO would make just for the prestige and personal relationship.

H. L. Petersen and Vredenburg (2009) studied the linkages between CSR, firm performance, and institutional investors decisions before investing in a firm, and whether to hold or sell after having made the decisions, however, their results indicated that those investors have expressed stronger commitment to both maintaining a 
CSR level, and also building on this CSR performance, four dimensions were determined based on their results are to be the sources of the profit generating and performance improving: risk mitigating, creating and capturing market opportunities, accruing capital market advantages, and improving the quality and performance of management. Thus, it is in the best interest of those institutional investors to capture as much value as they can by using their external connections with other major entities either governmental, social, non-governmental, and other organizations in the context in which their firms maneuver.

Institutional investors then can use these connections to make the turn the corporate social engagements into advantages and make it profitable at the same time.

It should also be noted, that institutional investors, once they are in, they are better able to make the fit between any projected social engagements and the firm's best interests, also they are better able to minimize any losses by giving credibility to the firm's actions (H. Petersen \& Vredenburg, 2009).

Graves and Waddock (1994) found that institutions tend to be more attracted to firms that have better CSR ranking, which provides support that these institutions do consider CSR rankings and social performance in their evaluation. Also, Ntim and Soobaroyen (2013) found that better-governed firms are more likely to pursue courses of actions that are socially responsible, and also found increased commitment towards socially responsible activities, which was reflected in improved financial performance.

Proposition 3: The level of CSR will be positively related with the proportion of institutional owners.

Proposition 4: The proportion of institutional owners in a firm will positively moderate the relationship between the firm's level of CSR and the firm financial performance.

\section{Discussion and Implications}

This revision sheds light on how corporate social responsibility as a social aspect of firm's engagement with the peripheral environment, as well as its approach towards internal constituents may advantage a firm. The study builds on researchers' requests for more integrative approaches that would incorporate additional central dynamics, through which such social initiatives would pay off. The model presented in this study focuses mainly on two dimensions: first: the ownership structure of the firm and its impact on the firm's strategy vis-à-vis the socially responsible conducts and undertakings, in particular, the presence of institutional investors and their impact on a firm's strategies in the social domain. Second, the role of publicity and firm's reputation in enhancing the positive impact of socially responsible behaviors and activities, and how consistency, integrity, and appropriate courses of actions may enhance the positive role of CSR.

The study contributes to the literature in several ways. First, the previous studies tend to focus on the relationship between CSR and firm performance, regardless any other strategic factors; such as the firm's reputation, publicity of its social activities, public reach of the firm, and some other strategic factors that tend to play significant role in determining the extent to which a firm may benefit from its social engagement and contributions. Also, the study shed light on the importance of the fit between the social initiatives the firm makes and the stakeholders' expectations. Second, the study focuses more on the role of institutional investors in moderating the relationship between the CSR activities and the firm financial performance, the strategy scholars have studied the relationship between such investors and the firm's critical decisions such as diversification, international diversification, and some other aspects of strategic actions. However, there is a consensus that CSR has become a business strategy in recent years, as much as it is a response to external pressures from several constituents in the external environment, such as government, suppliers, consumers, and non-governmental organizations. That said, combined with the findings of previous studies that CSR is one important criterion used by institutional investors to make their investment decisions, it is very important to study their impact after they have made their decisions in investing in socially responsible firms.

The study also extends the existing research on the relationship between CSR and firm performance, it will provide additional support for the previous research findings regarding this relationship.

The study has also practical implications for managers, it presents an evidence on the importance of media relations, public relations, firm interaction with consumers, suppliers, competitors, and all stakeholders who matter to the firm as to ensure that they fully understand the firm message and also make them aware of its socially responsible behavior so the firm can capitalize on such publicly established reputation. The study also provides a managerial implication on how managers can benefit from the expertise of institutional investors in the external environment with respect to their information about the society needs and most important activities to the greater proportion of the stakeholders who matter. In so doing, managers can have more appropriate and precise information regarding the type and timing of any planned social initiatives. The study also presents an 
evidence that managers can benefit from the presence of institutional investors in the sense that they can benefit from their networks with the external constituents, and build on these networks by improving the firm image and reputation.

\section{Conclusions}

In the recent years, CSR has become a major field of interest for scholars in the business domain. Researchers from different disciplines such as finance, management, and economics have been focusing on the firm's social duties, the dimensions of these duties, and the extent to which such duties may help the firm financially. The present study examines the under-researched issue of the factors that would enable a positive effect of the firm social activities and ethical behaviors.

I focus on the effect of publicity of firm socially responsible initiatives, and the role of institutional investors in moderating the effect of CSR on firm performance.

The expected findings will suggest that the more consistent, integrative, and appropriate the firm's social initiatives, the more positive impact it will have on the firm performance. These three factors, I propose that they will be represented by the firm reputation, the reputation is used as proxy of the publicity of the firm social activities. The findings will suggest that as the firm engages in socially responsible initiatives and activities, it is expected that these activities will have a positive impact on the firm performance when it can be seen by larger number of constituents and stakeholders. The publicity of the firm's activities can positively moderate the relationship between the CSR activities and the financial performance.

The expected findings would also suggest that, as the institutional investors consider CSR as important criterion in making their investment decisions, it is expected that they will align such social initiatives with the best interest of the firm. They are also expected to have more information on the external environment, as to where, when, and how to initiate social activities that would meet stakeholders demands, expectations, and in the meantime benefit the firm financially.

\section{Limitations and Future Research}

It should be noted that there are several limitations are inherent in this proposal. One possible weakness the reader may see in this study is the operationalization of reputation as a proxy of the firm's CSR activities publicity. Precise measure that would capture exactly what I propose herein could be a major question. There has not been a common measure that is used agreeably among scholars, especially in capturing the publicity of the CSR activities. One may suppose that we could use the firm's disclosure, however, this might be the easy way but there will still be another weakness which would be the resultant of the self-report bias. In fact, some scholars have used the firm social medial fan volume to capture such construct, (Berens \& Li, 2013) for example conducted an experimental study and examined the effect of the level of corporate involvement in its social media channels (Twitter) and its impact on users reactions and corporate reputations. (R. Wang, 2013) used a survey methodology to capture the perceived reputation of a firm from a job applicants' perspective, and that job applicants would prefer firms that has a good reputation and are socially responsible. It appears that each research is limited and constrained by the purpose of the study, as in this study, I have tried to show the available measure that is common, captures the most variance among selected firms, and that also has been used in the literature and not susceptible to validity threats.

Another weakness is the use of cross-sectional design, there could be a stronger and rigorous design which is a cross-lagged design, but for the purpose of this study, I should note that future empirical tests may use cross-sectional design as due to the lack of full access to datasets, and the lack of appropriate statistical techniques for the time being. However, the use of cross-lagged design would result in more precise measures and more appealing and truthful results.

On the positive side, however, this paper would open a new avenue that allows scholars to study different governance mechanisms and the CSR feasibility associated with each type of governance. The study may be of importance as to further explore the interrelationships between corporate governance, ownership structure, along with the corporate social responsibility practices. A future work may elaborate more in creating more vigorous measure of the publicity of the firm social initiatives and activities that would include actual stakeholders responses, not only competitors as the case in Fortune index, but also other stakeholders such as government, consumers, suppliers, and non-governmental organizations.

\section{References}

Ahmed, S. U., Islam, Z., Mahtab, H., \& Hasan, I. (2014). Institutional investment and corporate social performance: Linkage towards sustainable development. Corporate Social Responsibility and 
Environmental Management, 21(1), 1-13. http://dx.doi.org/10.1002/csr.1298

Almsafir, M. K. (2014). Does corporate social responsibility lead to improve in firm financial performance? Evidence from malaysia. International Journal of Economics and Finance, 6(3), 126-138. http://dx.doi.org/10.5539/ijef.v6n3p126

Andersen, M. L., \& Olsen, L. (2011). Corporate social and financial performance: A canonical correlation analysis. Academy of Accounting and Financial Studies Journal, 15(2), 17.

Attig, N., El Ghoul, S., Guedhami, O., \& Suh, J. (2013). Corporate social responsibility and credit ratings. Journal of Business Ethics, 117(4), 679-694. http://dx.doi.org/10.1007/s10551-013-1714-2

Barnett, M. L. (2007). Stakeholder influence capacity and the variability of financial returns to corporate social responsibility. The Academy of Management Review, 32(3), 794-816.

Berens, G., \& Li, T. (2013). Corporate twitter channels: The impact of engagement and informedness on corporate reputation. International Journal of Electronic Commerce, 18(2), 97-125. http://dx.doi.org/10.2753/JEC1086-4415180204

Branco, M. C., \& Rodrigues, L. L. (2006). Corporate social responsibility and resource-based perspectives. Journal of Business Ethics, 69(2), 111-132. http://dx.doi.org/10.1007/s10551-006-9071-z

Bushee, B. J. (1998). The influence of institutional investors on myopic R\&D investment behavior. The Accounting Review, 73(3), 305-333.

Campbell, J. L. (2007). Why would corporations behave in socially responsible ways? An institutional theory of corporate social responsibility. The Academy of Management Review, 32(3), 946-967.

Cochran, P. L., \& Wood, R. A. (1984). Corporate social responsibility and financial performance. The Academy of Management Journal, 27(1), 42-56.

Cox, P., Brammer, S., \& Millington, A. (2004). An empirical examination of institutional investor preferences for corporate social performance. Journal of Business Ethics, 52(1), 27-43. http://dx.doi.org/10.1023/B:BUSI.0000033105.77051.9d

David, P., Kochhar, R., \& Levitas, E. (1998). The effect of institutional investors on the level and mix of CEO compensation. The Academy of Management Journal, 41(2), 200-208.

Dhaliwal, D., Li, O. Z., Tsang, A., \& Yang, Y. G. (2014). Corporate social responsibility disclosure and the cost of equity capital: The roles of stakeholder orientation and financial transparency. Journal of Accounting and Public Policy, 33(4), 328-355.

Dickinson-Delaporte, S., Beverland, M., \& Lindgreen, A. (2010). Building corporate reputation with stakeholders. European Journal of Marketing, 44(11/12), 1856-1874. http://dx.doi.org/10.1108/03090561011079918

Donker, H., Poff, D., \& Zahir, S. (2008). Corporate values, codes of ethics, and firm performance: A look at the canadian context. Journal of Business Ethics, 82(3), 527-537. http://dx.doi.org/10.1007/s10551-007-9579-x

Dutton, J. E., \& Dukerich, J. M. (1991). Keeping an eye on the mirror: Image and identity in organizational adaptation. The Academy of Management Journal, 34(3), 517-554.

Ekatah, I., Samy, M., Bampton, R., \& Halabi, A. (2011). The relationship between corporate social responsibility and profitability: The case of royal dutch shell plc. Corporate Reputation Review, 14(4), 249-261. http://dx.doi.org/10.1057/crr.2011.22

El Ghoul, S., Guedhami, O., Kwok, C. C. Y., \& Mishra, D. R. (2011). Does corporate social responsibility affect the cost of capital? Journal of Banking \& Finance, 35(9), 2388-2406. http://dx.doi.org/10.1016/j.jbankfin.2011.02.007

Ferreira, M. A., \& Matos, P. (2008). The colors of investors' money: The role of institutional investors around the world. Journal of Financial Economics, 88(3), 499-533. http://dx.doi.org/10.1016/j.jfineco.2007.07.003

Freeman, R. E. (1984). Strategic management: A stakeholder approach. Boston: Pitman.

Gove, S., \& Janney, J. J. (2011). Reputation and corporate social responsibility aberrations, trends, and hypocrisy: Reactions to firm choices in the stock option backdating scandal. Journal of Management Studies, 48(7), 1562-1585. http://dx.doi.org/10.1111/j.1467-6486.2010.00984.x

Graves, S. B., \& Waddock, S. A. (1994). Institutional owners and corporate social performance. The Academy of 
Management Journal, 37(4), 1034-1046.

Hall, R. (1992). The strategic analysis of intangible resources. Strategic Management Journal, 13(2), 135-144. http://dx.doi.org/10.1002/smj.4250130205

Hartzell, J. C., \& Starks, L. T. (2003). Institutional investors and executive compensation. The Journal of Finance, 58(6), 2351-2374. http://dx.doi.org/10.1046/j.1540-6261.2003.00608.x

Hatch, M. J. (1993). The dynamics of organizational culture. The Academy of Management Review, 18(4), 657-693.

Herremans, I. M., Akathaporn, P., \& McInnes, M. (1993). An investigation of corporate social responsibility reputation and economic performance. Accounting, Organizations and Society, 18(7), 587-604. doi:10.1016/0361-3682(93)90044-7

Hillman, A. J., \& Keim, G. D. (2001). Shareholder value, stakeholder management, and social issues: What's the $\begin{array}{lllll}\text { bottom line? Strategic } & \text { Management }\end{array}$ doi:10.1002/1097-0266(200101)22:2<125::AID-SMJ150>3.0.CO;2-H

Hond, F., Rehbein, K. A., Bakker, F. G. A., \& Lankveld, H. K. (2014). Playing on two chessboards: Reputation effects between corporate social responsibility (CSR) and corporate political activity (CPA). Journal of Management Studies, 51(5), 790-813. http://dx.doi.org/10.1111/joms.12063

Hooghiemstra, R. (2000). Corporate communication and impression management: New perspectives why companies engage in corporate social reporting. Journal of Business Ethics, 27(1/2), 55-68. http://dx.doi.org/10.1023/A:1006400707757

Hull, C. E., \& Rothenberg, S. (2008). Firm performance: The interactions of corporate social performance with innovation and industry differentiation. Strategic Management Journal, 29(7), 781-789. http://dx.doi.org/10.1002/smj.675

Hull, C. E., \& Tang, Z. (2012). How corporate social responsibility engagement strategy moderates the CSR-financial performance relationship. Journal of Management Studies, 49(7), 1274-1303. http://dx.doi.org/10.1111/j.1467-6486.2012.01068.x

Jennings, P. D., \& Zandbergen, P. A. (1995). Ecologically sustainable organizations: An institutional approach. The Academy of Management Review, 20(4), 1015-1052.

Jiraporn, P., Jiraporn, N., Boeprasert, A., \& Chang, K. (2014). Does corporate social responsibility (CSR) improve credit ratings? Evidence from geographic identification. Financial Management, 43(3), 505-531. http://dx.doi.org/10.1111/fima.12044

Kemper, J., Schilke, O., Reimann, M., Wang, X., \& Brettel, M. (2013). Competition-motivated corporate social $\begin{array}{llll}\text { responsibility. Journal of Business } & \text { Research, 66(10), }\end{array}$ http://dx.doi.org/10.1016/j.jbusres.2013.02.018

Lin, F., \& Wu, S. (2014). Corporate social responsibility and cost of capital: An empirical study of the taiwan stock market. Emerging Markets Finance \& Trade, 50(s1), 107-120. http://dx.doi.org/10.2753/REE1540-496X5001S107

Maignan, I., \& Ferrell, O. C. (2004). Corporate social responsibility and marketing: An integrative framework. Journal of the Academy of Marketing Science, 32(1), 3-19.

Maitland, A. (2003). Tools to build a reputation: Corporate Social Responsibility: Some companies are using pay and appraisals to encourage CSR among managers, writes alison maitland: London edition. Financial Times.

Mallin, C. A., \& Michelon, G. (2011). Board reputation attributes and corporate social performance: An empirical investigation of the US best corporate citizens. Accounting and Business Research, 41(2), 119-144. http://dx.doi.org/10.1080/00014788.2011.550740

McGuire, J. B., Sundgren, A., \& Schneeweis, T. (1988). Corporate social responsibility and firm financial performance. The Academy of Management Journal, 31(4), 854-872.

McWilliams, A., \& Siegel, D. (2001). Corporate social responsibility: A theory of the firm perspective. The Academy of Management Review, 26(1), 117-127.

Mukherjee, A., \& He, H. (2008). Company identity and marketing: An integrative framework. Journal of Marketing Theory and Practice, 16(2), 111-125. http://dx.doi.org/10.2753/MTP1069-6679160202 
Ntim, C. G., \& Soobaroyen, T. (2013). Corporate governance and performance in socially responsible corporations: New empirical insights from a Neo - Institutional framework. Corporate Governance: An International Review, 21(5), 468-494. http://dx.doi.org/10.1111/corg.12026

Oikonomou, I., Brooks, C., \& Pavelin, S. (2014). The financial effects of uniform and mixed corporate social performance. Journal of Management Studies, 51(6), 898-925. http://dx.doi.org/10.1111/joms.12064

Petersen, H. L., \& Vredenburg, H. (2009). Morals or economics? Institutional investor preferences for corporate social responsibility. Journal of Business Ethics, 90(1), 1-14. http://dx.doi.org/10.1007/s10551-009-0030-3

Petersen, H., \& Vredenburg, H. (2009). Corporate governance, social responsibility and capital markets: Exploring the institutional investor mental model. Corporate Governance, 9(5), 610-622. http://dx.doi.org/10.1108/14720700910998175

Reverte, C. (2012). The impact of better corporate social responsibility disclosure on the cost of equity capital. Corporate Social Responsibility and Environmental Management, 19(5), 253-272. http://dx.doi.org/10.1002/csr.273

Riordan, C. M., Gatewood, R. D., \& Bill, J. B. (1997). Corporate image: Employee reactions and implications for managing corporate social performance. Journal of Business Ethics, 16(4), 401-412. http://dx.doi.org/10.1023/A:1017989205184

Russo, M. V., \& Fouts, P. A. (1997). A resource-based perspective on corporate environmental performance and profitability. The Academy of Management Journal, 40(3), 534-559.

Scott, R. W. (2014). Institutional investors, R\&D policy and firm stock liquidity. International Journal of Economics and Finance, 6(10), 26.

Sen, S., Bhattacharya, C. B., \& Korschun, D. (2006). The role of corporate social responsibility in strengthening multiple stakeholder relationships: A field experiment. Journal of the Academy of Marketing Science, 34(2), 158-166. http://dx.doi.org/10.1177/0092070305284978

Shapiro, C. (1983). Premiums for high quality products as returns to reputations. The Quarterly Journal of Economics, 98(4), 659-679.

Sur, S., \& Sirsly, C. T. (2013). What's in a name? Decomposing corporate reputation to assess the relative impact of temporal, firm and industry level factors. Journal of Management \& Governance, 17(4), 1047-1072. http://dx.doi.org/10.1007/s10997-012-9214-9

Thomsen, S., \& Pedersen, T. (2000). Ownership structure and economic performance in the largest european $\begin{array}{lllll}\text { companies. Strategic } & \text { Management }\end{array}$ http://dx.doi.org/10.1002/(SICI)1097-0266(200006)21:6<689::AID-SMJ115>3.0.CO;2-Y

Turban, D. B., \& Greening, D. W. (1997). Corporate social performance and organizational attractiveness to prospective employees. The Academy of Management Journal, 40(3), 658-672. Retrieved from http://www.jstor.org.ezproxy.uta.edu/stable/257057

Vlachos, P. A., Tsamakos, A., Vrechopoulos, A. P., \& Avramidis, P. K. (2009). Corporate social responsibility: Attributions, loyalty, and the mediating role of trust. Journal of the Academy of Marketing Science, 37(2), 170-180. http://dx.doi.org/10.1007/s11747-008-0117-x

Waddock, S. A., \& Graves, S. B. (1995). Attraction or Repulsion: How Institutional Owners React to Corporate Social Performance. Management Research News, 18(12), 20-24. http://dx.doi.org/10.1108/eb028430

Waddock, S. A., \& Graves, S. B. (1997). The corporate social performance-financial performance link. Strategic Management Journal, $303-319$. http://dx.doi.org/10.1002/(SICI)1097-0266(199704)18:4<303::AID-SMJ869>3.0.CO;2-G

Wang, H., \& Choi, J. (2013). A new look at the corporate social-financial performance relationship: The moderating roles of temporal and interdomain consistency in corporate social performance. Journal of Management, 39(2), 416-441. http://dx.doi.org/10.1177/0149206310375850

Wang, R. (2013). Modeling corporate social performance and job pursuit intention: Mediating mechanisms of corporate reputation and job advancement prospects. Journal of Business Ethics, 117(3), 569-582. http://dx.doi.org/10.1007/s10551-012-1538-5

Weigelt, K., \& Camerer, C. (1988). Reputation and corporate strategy: A review of recent theor. Strategic Management Journal, 9(5), 443. 
Wright, P., Ferris, S. P., Sarin, A., \& Awasthi, V. (1996). Impact of corporate insider, blockholder, and institutional equity ownership on firm risk taking. The Academy of Management Journal, 39(2), 441-463.

Wrolstad, M. A., \& Krueger, T. M. (2010). Contemporaneous relationship between corporate reputation and return. Managerial Finance, 36(6), 482-490. http://dx.doi.org/10.1108/03074351011042964

\section{Copyrights}

Copyright for this article is retained by the author(s), with first publication rights granted to the journal.

This is an open-access article distributed under the terms and conditions of the Creative Commons Attribution license (http://creativecommons.org/licenses/by/3.0/). 